\title{
Kepemilikan Rumah Susun Di Indonesia
}

\author{
R. Suharto, Siti Malikhatun Badriyah, Kashadi \\ Fakultas Hukum Universitas Diponegoro \\ JL. Prof. Sudharto No. 1 Semarang, Jawa Tengah, 50275 \\ r.suhartoo@gmail.com
}

\begin{abstract}
Technologically, a multi-storey building system whose spaces can be used individually has long been known in Indonesia. The system of building ownership is a single ownership system that is now being developed which is ownership of a multi-storey building with shared property, which is called rumah susun, condominium, or strata title. Ownership of Satuan Rumah Susun (HMSRS) is a new institution of material rights, this HMSRS is individual and separate, in addition to ownership of the apartment unit the ownership rights to the apartment unit (HMSRS) concerned also include joint ownership of what is called a joint part, shared objects, and shared land where all are inseparable from the SRS concerned.
\end{abstract}

Keywords: rumah susun, ownership.

\section{ABSTRAK}

Secara teknologi, sistem Gedung bertingkat yang ruang-ruangnya dapat dipakai secara individu sudah lama dikenal di Indonesia. Sistem pemilikan Gedung tersebut adalah sistem pemilikan tunggal yang sekarang dikembangkan adalah kepemilikan Gedung bertingkat dengan milik bersama, yang disebut dengan rumah susun, kondominium, atau strata title. Hak Milik Satuan Rumah Susun (HMSRS) merupakan suatu Lembaga baru hak kebendaan, HMSRS ini bersifat perorangan dan terpisah, selain pemilikan atas satuan rumah susun hak pemilikan atas satuan rumah susun (HMSRS) yang bersangkutan meliputi juga kepemilikan bersama atas apa yang disebut bagian bersama, benda bersama, dan tanah bersama di mana semuanya merupakan suatu kesatuan yang tidak terpisahkan dengan SRS yang bersangkutan.

Kata kunci: rumah susun, kepemilikan.

\section{PENDAHULUAN}

Kebutuhan akan rumah sebagai tempat tinggal atau hunian di perkotaan sangat besar seiring dengan besarnya jumlah penduduk, baik yang berasal dari pertumbuhan alamiah melalui kelahiran, maupun urbanisasi. Selama ini pemenuhan kebutuhan akan rumah sebagai tempat tinggal atau hunian di perkotaan dilakukan melalui pembangunan 
perumahan secara horizontal. Cara pemenuhan kebutuhan ini tidak dapat dilakukan secara terus-menerus disebabkan oleh persediaan tanah di perkotaan yang sangat terbatas . ${ }^{1}$

Oleh karena itu untuk menyelesaikan persoalan tersebut manusia mulai berkreasi untuk membuat rumah-rumah yang tersusun secara vertikal, sehingga jumlah tanah yang tetap tidak lagi berpengaruh terhadap ketersediaan rumah sebagai kebutuhan hidup manusia. Kepemilikan bersama dalam tempat tinggal ini yang kemudian disebut dengan Rumah Susun, kondominium, strata title. Siswonoyudohusodo menyatakan bahwa membangun rumah susun di kota-kota besar adalah kecenderungan masa depan yang tidak dapat dihindari, yang memang perlu dimasyarakatkan dan perlu ada penyesuaian pada budaya-budaya yang ada pada masyarakat Indonesia².

Kondominium atau Rumah Susun adalah beberapa istilah yang mengacu pada rumah yang tersusun secara vertikal. Condominium menurut arti kata berasal dari Bahasa latin yang terdiri dari dua kata yaitu Con berarti ber sama-sama dan dominium berarti pemilikan ${ }^{3}$, dengan demikian maka arti condominium adalah kepemilikan bersama. Di Indonesia sendiri terdapat beberapa istilah yang rekat dengan pengertian condominium maupun strata title, seperti apartemen dan rumah susun. Namun demikian dalam Bahasa hukum Indonesia, baik yang dimaksud dengan strata title, condominium, apartemen, dan rumah susun diatur dalam satu Undang-Undang yang menggunakan istilah Rumah Susun.

\section{PEMBAHASAN}

\section{Konsep Dasar Pemilikan Rumah Susun}

Secara teknologi, sistem bangunan Gedung bertingkat yang ruang-ruangnya dapat dipakai secara individual sudah lama dikenal dan dilaksankan di beberapa kota-kota besar di Indonesia. Sistem pemilikan gedung tersebut adalah sistem pemilikan tunggal, di mana pemegang hak atas tanah sekaligus sebagai pemilik Gedung. Pemakai-pemakai pada sistem pemilikan sebagaimana tersebut di atas hanya terikat dalam bentuk hubungan hukum sewamenyewa, yang tidak memberikan hak kebendaan atas obyek perjanjian sehingga pemanfaatannya bagi yang bersangkutan sangat terbatas. Pemilikan tunggal dilihat dari

\footnotetext{
${ }^{1}$ Urip Santoso, Hak atas Tanah, Hak Pengelolaan dan Hak Milik atas Satuan Rumah Susun, Depok, Kencana, 2017, hal. 213.

${ }^{2}$ Siswonoyudohusodo, dalam Urip Santoso, Ibid.

${ }^{3}$ Ari, S Hutagalung, Condominium dan Permasalahannya, Jakarta, Diktat Fakultas Hukum, 2017.
} 
pemilikan tanah tempat Gedung bertingkat itu berdiri sehingga pemegang sertipikat juga merupakan pemilik Gedung.

Hak Milik Satuan Rumah Susun (HMSRS) merupakan suatu Lembaga baru hak kebendaan yang diperkenalkan melalui UU Rumah Susun menurut UURS, HMSRS ini bersifat perorangan dan terpisah. Selain pemilikan atas Satuan Rumah Susun (SRS), HMSRS yang bersangkutan meliputi juga hak kepemilikan bersama atas apa yang disebut bagian bersama, benda bersama, dan tanah bersama, di mana semuanya merupakan satu kesatuan yang tidak terpisahkan dengan SRS yang bersangkutan ${ }^{4}$

Konsep dasar yang melandasi HMSRS itu sendiri berpangkal pada teori-teori tentang pemilikan atas suatu benda. Menurut hukum, suatu benda/bangunan dapat dimiliki oleh seseorang, dua orang atau bahkan lebih, yang dikenal dengan istilah pemilikan bersama. Dalam pemilikan bersama atas suatu benda/bangunan pada pokoknya dikenal 2 (dua) bentuk pemilikan, yaitu :

a. Pemilikan bersama yang terikat (gebonden mede eigendom), maka dasar utamanya adalah ikatan hukum yang terlebih dahulu ada di antara para pemilik benda bersamanya. Misalnya: Pemilikan bersama yang terdapat pada harta perkawinan, atau harta peninggalan. Para pemilik bersama (mede eigendom) tidak dapat bebas memindahkan haknya kepada orang lain tanpa persetujuan mede eigenaar lainnya, atau selama suami isteri masih dalam ikatan perkawinan tidak dimungkinkan mengadakan pemisahan dan pembagian harta perkawinan.

b. Pemilikan bersama yang bebas (vrije mede eigendom), maka antara para pemilik bersama tidak terdapat ikatan hukum terlebih dahulu, selain dari hak bersama menjadi pemilik dari suatu benda. Di sini ada kehendak untuk bersama-sama menjadi pemilik atas suatu benda untuk digunakan bersama.

Bentuk pemilikan bersama yang bebas inilah yang menurut Hukum Romawi disebut "CONDOMINIUM" yang penerapannya diatur dengan Undang-Undang.

Berdasarkan konsep tersebut, maka dalam UURS dirumuskan suatu jenis pemilikan perseorangan dan pemilikan bersama dalam satu paket jenis pemilikan yang baru yang disebut Hak Milik Atas Satuan Rumah Susun, dengan pengertian sebagaimana diuraikan di atas yaitu hak

\footnotetext{
${ }^{4}$ M.Rizal Alif, Analisis Kepemilikan Ha katas Tanah Satuan Rumah Susun di dalam Kerangka Hukum Benda, Bandung, CV. Nuansa Aulia, 2009, hal. 75.
} 
pemilikan perseorangan atas satuan (unit) rumah susun, meliputi pula hak bersama atas bangunan, benda dan tanahnya.

Disamping konsep HMSRS tersebut, UU Rumah Susun yang baru yaitu UU No.20 Tahun 2011 memperkenalkan konsep baru, dengan pemilikan tanpa Hak Atas Tanah karena Hak Atas Tanah dimiliki oleh orang lain bukan pemilik Satuan Rumah Susun, sebagai tanda bukti kepemilikan atas Satuan Rumah Susun tersebut. Pemilik (Atas Satuan Rumah Susun) diterbitkan Sertifikat Kepemilikan Bangunan Gedung (SKBG).

\section{Obyek dan Subyek atas Satuan Rumah Susun}

Pasal 17 UU No. 20 Tahun 2011 tentang Rumah Susun menetapkan rumah susun dapat dibangun di atas tanah ;

a. Hak Milik

b. Hak Guna Bangunan atau Hak Pakai atau Tanah Negara ; dan

c. Hak Guna Bangunan atau Hak Pakai di Atas Hak Pengelolaan

Berikut akan diuraikan jenis-jenis Hak Atas Tanah yang dapat digunakan untuk pembangunan Rumah Susun :

1. Hak Milik Hak Milik adalah hak turun temurun, terkuat dan terpenuh yang dapat dipunyai oleh warga negara Indonesia dan badan-badan hukum tertentu yang ditunjuk dalam Peraturan Pemerintah Nomor 38 Tahun 1963. Seperti :

a. Bank-Bank Pemerintah

b. Koperasi Pertanian

c. Badan-Badan Keagamaan

d. Badan-Badan Sosial

Kesemuanya dengan catatan ditunjuk Pemerintah setelah mendengar Menteri yang mempunyai yurisdiksi atas badan-badan tersebut di atas.

Mengingat bahwa pemilik rumah susun dan pemilik satuan rumah susun harus memenuhi syarat sebagai pemegang hak atas tanah di atas mana rumah susun didirikan, maka satuan rumah susun yang dibangun atas tanah dengan hak milik hanya terbatas pemilikannya pada perseorangan warga negara Indonesia dan badan-badan hukum yang ditunjuk berdasarkan PP No.38 Tahun 1963 tersebut.

2. Hak Guna Bangunan atas Tanah Negara 
Pelaku pembangunan rumah susun yang membangun rumah susun di atas tanah Hak Guna Bangunan atas Tanah Negara adalah warga negara Indonesia, badan hukum yang didirikan menurut hukum Indonesia dan berkedudukan di Indonesia, misalnya badan usaha swasta yang berbentuk Perseroan Terbatas (PT).

3. Hak Guna Bangunan atas Tanah Hak Pengelolaan

Pelaku pembangunan rumah susun yang membangun rumah susun di atas tanah Hak Guna Bangunan atas Tanah Hak Pengelolaan adalah Badan Usaha Milik Negara yang berbentuk Perusahaan Umum Pembangunan Perumahan Nasional (Perum Perumnas).

4. Hak Pakai atas Tanah Negara

Pelaku pembangunan rumah susun yang membangun rumah susun di atas tanah Hak Pakai atas Tanah Negara adalah warga negara Indonesia, orang asing yang berkedudukan di Indonesia, Kementerian, Lembaga Pemerintah Non Kementerian, Badan Usaha Milik Negara, Badan Usaha Milik Daerah, Badan Otorita, Badan Keagamaan, Badan Sosial, Badan Usaha Swasta yang berbentuk Perseroan Terbatas (PT).

5. Hak Pakai atas Tanah Hak Pengelolaan

Pelaku pembangunan rumah susun yang membangun rumah susun di atas tanah Hak Pakai atas Tanah Hak Pengelolaan adalah Badan Usaha Milik Negara yang berbentuk Perusahaan Umum Pembangunan Perumahan Nasional (Perum Perumnas).

Selain dibangun di atas tanah sebagaimana disebutkan di atas, rumah susun umum dan/ atau rumah susun khusus dapat dibangun dengan :

a. Pemanfaatan barang milik negara/daerah berupa tanah

Pemanfaatan barang milik negara/daerah berupa tanah untuk pembangunan rumah susun dilakukan dengan cara sewa atau kerja sama pemanfaatan.

b. Pendayagunaan tanah wakaf

Pendayagunaan tanah wakaf untuk pembangunan rumah susun dilakukan dengan cara sewa atau kerja sama pemanfaatan sesuai dengan ikrar wakaf.

\section{Persyaratan Pembangunan Rumah Susun}

Menurut Pasal 24 UU No. 20 Tahun 2011 tentang Rumah Susun, persyaratan pembangunan Rumah Susun meliputi Persyaratan administrasi, persyaratan teknis, dan persyaratan ekologis.

a. Persyaratan administrasi 
Vol 2, No. (2019): Law, Development \& Justice Review, Mei 2019. e-ISSN: 2655-1942

Persyaratan administrasi berdasarkan Pasal 28 Undang-Undang Nomor 20 Tahun 2011 yaitu meliputi :

- Status Hak Atas Tanah ;

- Izin Mendirikan Bangunan (IMB).

b. Persyaratan teknis

Persyaratan teknis berdasarkan Pasal 35 Undang-Undang Nomor 20 Tahun 2011 yaitu meliputi :

- Tata bangunan yang meliputi persyaratan peruntukan lokasi serta intensitas dan arsitektur bangunan ; dan

- Keandalan bangunan yang meliputi persyaratan keselamatan, kesehatan, kenyamanan, dan kemudahan.

c. Persyaratan ekologis

Persyaratan ekologis berdasarkan Pasal 37 dan 38 Undang-Undang Nomor 20 Tahun 2011 yaitu merupakan persyaratan yang memenuhi analisis dampak lingkungan dalam hal pembangunan rumah susun yaitu mencakup keserasian dan keseimbangan fungsi lingkungan serta dilengkapi dengan dokumen pengelolaan lingkungan hidup. Yang dimaksud dokumen pengelolaan lingkungan hidup adalah dokumen yang diperlukan bagi penanggung jawab usaha dan/atau kegiatan yang berdampak bagi lingkungan dalam proses perizinan. Dokumen tersebut dapat berupa:

- Analisis Mengenai Dampak Lingkungan (AMDAL); atau

- Upaya Pengelolaan Lingkungan Hidup dan Upaya Pemantauan Lingkungan Hidup (UKL-UPL).

Selain persyaratan administrasi, persyaratan teknis dan persyaratan ekologis, pembangunan rumah susun harus mendapatkan Izin Bupati/Walikota tentang rencana fungsi dan pemanfaatan rumah susun. Permohonan izin tersebut diajukan oleh pelaku pembangunan dengan melampirkan persyaratan :

a. Sertifikat hak atas tanah;

b. Surat keterangan rencana kabupaten/kota;

c. Gambar rencana tapak;

d. Gambar rencana arsitektur yang memuat denah, tampak, dan potongan rumah susun yang menunjukkan dengan jelas batasan secara vertikal dan horizontal dari rumah susun; 
Vol 2, No. (2019): Law, Development \& Justice Review, Mei 2019. e-ISSN: 2655-1942

e. Gambar rencana struktur beserta perhitungannya;

f. Gambar rencana yang menunjukkan dengan jelas bagian bersama, benda bersama, dan tanah bersama; dan

g. Gambar rencana utilitas umum dan instalasi beserta perlengkapannya.

Pelaku pembangunan setelah mendapatkan izin Bupati/Walikota tentang rencana fungsi dan pemanfaatan rumah susun, wajib meminta pengesahan dan pemerintah daerah tentang pertelaan yang menunjukkan batas yang jelas dari setiap sarusun, bagian bersama, benda bersama, dan tanah bersama beserta uraian Nilai Perbandingan Proporsional atau NPP. Hal tersebut ditegaskan dalam Pasal 30 Undang-Undang Nomor 20 Tahun 2011 tentang rumah susun.

\section{Pemasaran dan Penjualan Rumah Susun}

Saat ini telah berkembang suatu kebiasaan di dunia bisnis perumahan untuk memasarkan rumah susun yang sedang dibangun atau bahkan belum dibangun, yaitu penjualan dengan system Pre Project Selling. Tahun 1967, hukum Perancis telah berurusan dengan penjualan unit dari suatu rencana pembangunan menggunakan tipe perjanjian yang khusus, yang dikenal sebagai penjualan sebuah bangunan yang akan dibangun ( $a$ sale of a building to be constructed). Berdasarkan perjanjian tersebut, pembeli akan membayar sejumlah uang awal kepada pengembang diikuti dengan pembayaran yang berturut-turut seiring dengan berjalannya pembangunan, kemudian pembeli akan menjadi pemilik bangunan secara bertahap, dan pembeli dilindungi oleh hukum mana kala bangunan tidak selesai dibangun oleh pengembang. Alasan mengapa pengembang diperbolehkan menerima uang dan angsuran dari pembeli sebelum bangunan selesai adalah untuk memastikan bahwa pengembang dalam posisi dapat membiayai pembangunan Gedung. Pengembang dapat meminjam lebih mudah dari Lembaga keuangan dan pengembang kemudian dapat membayar kontraktor bangunan dengan uang yang diperolehnya dari pembeli. Untuk Indonesia, penjualan dengan sistem Pre Project Selling dilakukan dengan membuat Perjanjian Perikatan Jual Beli (PPJB). PPJB adalah kesepakatan dari dua pihak untuk melaksanakan prestasi masing-masing di kemudian hari, yakni pelaksanaan jual beli di hadapan Pejabat Pembuat Akta Tanah (PPAT), bila bangunan telah selesai, bersertifikat, dan layak huni. PPJB dibuat sebagai perjanjian pendahuluan yang bertujuan untuk mengikat para pihak sebelum dibuatnya Akta Jual Beli (AJB) di hadapan PPAT. AJB ini merupakan suatu akta 
otentik yang dibuat oleh PPAT sebagai bukti untuk peralihan ha katas tanah dan bangunan. AJB inilah yang nantinya akan digunakan untuk pengajuan pendaftaran peralihan hak ke kantor pertanahan setempat atau yang lebih dikenal dengan istilah balik nama. Dengan selesainya proses balik nama, maka hak yang melekat pada tanah dan bangunan telah berpindah dari penjual ke pembeli. PPJB ini merupakan perjanjian standar yang umumnya dibuat oleh pengembang. Mengingat yang membuat PPJB adalah pengembang, tentunya ada kecenderungan faktor subyektif yang menguntungkan pengembang dan dapat merugikan pembeli. ${ }^{5}$ Posisi pengembang yang dominan ini membuka peluang untuk cenderung menyalahgunakan kedudukannya. Banyak informasi yang tidak diberikan secara terbuka pada saat proses PPJB, misalnya terkait status kepemilikan tanah, spesifikasi bangunan, bagaimana jika terjadi keterlambatan penyerahan dan pelanggaran hak-hak kolektif pembeli yang dilakukan oleh pihak pengembang, misalnya terkait lahan parkir, taman, serta fasilitas-fasilitas lain yang diperjanjikan.

Strategi penjualan rumah susun dengan cara memasarkan rumah susun yang belum selesai dibangun atau bahkan belum dibangun merupakan strategi penjualan yang sering digunakan oleh para pengembang. Biasanya rumah susun yang dipasarkan masih dalam bentuk gambar/denah rumah susun saja, perizinan yang diwajibkan belum tuntas diurus, bahkan tidak jarang terjadi pada saat masih direncanakan dan pematangan tanah juga masih belum jelas lokasi tepatnya berada dimana. Strategi pemasaran rumah susun seperti ini dalam praktik dikenal dengan istilah Pre Project Selling. Strategi pemasaran dengan Pre Project Selling dianggap lebih rasional dan menguntungkan bagi pengembang karena dapat memanfaatkan pembayaran yang dilakukan oleh pembeli sebagai modal dalam melakukan pembangunan. Hal ini terdapat kepercayaan antara pengembang dan pembeli, yaitu pengembang percaya bahwa pembeli akan melunasi pembayaran sesuai dengan yang mereka sepakati. Secara yuridis formal pola penjualan rumah susun dengan sistem Pre Project Seling tidak dilarang. Dalam UU Rumah Susun pun memberikan saran untuk dilakukannya pemasaran yang seperti itu. Sebagaimana yang dijelaskan dalam Pasal 42 ayat 1 UU Rumah Susun, yang menyatakan bahwa pelaku pembangunan dapat melakukan pemasaran sebelum pembangunan rumah susun selesai dilaksanakan. Ketentuan yang mengatur secara spesifik terkait Pre Project Selling memang belum ada, oleh karena itu

\footnotetext{
5J, Andi Hartanto, "Karakteristik Hak Milik atas Satuan Rumah Susun dan Peralihannya Melakukan Jual Beli", Surabaya, Universitas Airlangga, 2015, hal. 106.
} 
landasan utama sebagai penentuan hak dan kewajiban para pihak terletak pada kebebasan berkontrak, sedangkan mekanisme penentuan hak dan kewajiban para pihak dituangkan dalam bentuk Perjanjian Perikatan Jual Beli (PPJB).

Berdasarkan pasal 43 ayat 2 UU No. 20 Tahun 2011 tentang Rumah Susun, proses jual beli satuan rumah susun yang dilakukan sebelum pembangunan selesai bisa dilakukan dengan membuat Perjanjian Perikatan Jual Beli (PPJB) yang dibuat di hadapan notaris, dengan syarat memenuhi kepastian akan :
a. Status kepemilkan tanah
b. Kepemilikan IMB
c. Ketersediaan, sarana dan fasilitas umum
d. Keterbangunan paling sedikit $20 \%$ (dua puluh persen)
e. Hal yang diperjanjikan

\section{SIMPULAN DAN SARAN}

Pembangunan perumahan di perkotaan selama ini dilakukan melalui pembangunan perumahan secara horizontal, tapi pola pembangunan seperti ini tidak dapat dilakukan secara terus-menerus karena keterbatasan lahan perumahan di perkotaan, maka perlu dibangun perumahan yang bersifat vertikal yang disebut dengan rumah susun.

Peraturan rumah susun di Indonesia diatur dalam Undang-Undang Nomor 16 Tahun 1985, yang diperbarui dengan Undang-Undang Nomor 20 Tahun 2011 tentang Rumah Susun dengan peraturan pelaksananya PP Nomor 4 Tahun 1988 tentang Rumah Susun.

\section{DAFTAR PUSTAKA}

Alif, M.Rizal, 2009, Analisis Kepemilikan Ha katas Tanah Satuan Rumah Susun di dalam Hak Atas Tanah, Jakarta: Kencana Prenada Media.

Hartanto, J. Andi, 2015, Karakteristik Hak Milik atas Satuan Rumah Susun dan Peralihannya Melakukan Jual Beli, Surabaya: Universitas Airlangga.

Hutagalung, Arie S., 2010, Condominium dan Permasalahannya Pendaftaran dan Peralihan Kerangka Hukum Benda, Bandung: Cv Nuansa Aulia.

Santoso, Urip, 2010, Pendaftaran dan Peralihan Hak Atas Tanah, Jakarta: Kencana Prenada Media. 
Vol 2, No. (2019): Law, Development \& Justice Review, Mei 2019. e-ISSN: 2655-1942

Sutedi, Adirian, 2010. Hukum Rumah Susun dan Apartemen, Jakarta: Sinar Grafika.

Undang-Undang No. 20 Tahun 2011 